\title{
Mobile Application Bimbingan Tugas Akhir Mahasiswa Pada Stmik Handayani Makassar Sebagai Media Pendukung Pembelajaran Daring
}

\author{
M. Adnan Nur ${ }^{1}$, Nurilmiyanti Wardhani ${ }^{2}$ \\ ${ }^{1,2}$ Teknik Informatika, STMIK Handayani Makassar
}

Coprespondent Author : nurilmi@handayani.ac.id

\begin{abstract}
This study aims to develop and test access between a mobile application built with the Apache Cordova framework and the Apache web server via hypertext transfer protocol (HTTP) using Object XHR from Javascript. The application was built using a case study of final project guidance at STMIK Handayani Makassar. This research was carried out using the research and development ( $R$ \& $D)$ method which consisted of several stages, namely the analysis stage including a review of the use of the Apache Cordova framework and web services, the design stage using a unified modeling language, the application creation stage and the testing stage using the blackbox method. The results showed that all application functions can access data from the web service. There is a difference in the server data request time when the application is run on the emulator (google chrome) and the application is installed directly on an android device with the MIUI OS and ColorOS operating systems. Request server data with the emulator is faster with a less significant time difference, namely the average time difference is only $41.76 \mathrm{~ms}$ for MIUI OS and $\mathbf{4 6 . 5 2} \mathrm{ms}$ for ColorOS.
\end{abstract}

Keyword - mobile application, apache cordova framework, web service, final project guidance.

Abstrak - Penelitian ini bertujuan untuk mengembangkan serta menguji akses antara mobile application yang dibangun dengan framework apache cordova dan web server apache melalui hypertext transfer protocol (HTTP) menggunakan Object XHR dari Javascript. Aplikasi yang dibangun menggunakan studi kasus bimbingan tugas akhir pada STMIK Handayani Makassar. Penelitian ini dilaksanakan menggunakan metode research and development ( $\mathrm{R} \& \mathrm{D})$ yang terdiri atas beberapa tahapan yaitu tahap analisis meliputi tinjauan terhadap penggunaan framework apache cordova dan web service, tahap perancangan menggunakan unified modelling language, tahap pembuatan aplikasi dan tahap pengujian menggunakan metode blackbox. Hasil penelitian menunjukkan bahwa seluruh fungsi aplikasi dapat mengakses data dari web service. Terdapat perbedaan waktu request data server ketika aplikasi dijalankan pada emulator (google chrome) dan aplikasi yang diinstalasi langsung pada perangkat android dengan sistem operasi MIUI OS dan ColorOS. Request data server dengan emulator lebih cepat dengan perbedaan waktu yang tidak begitu signifikan yaitu rata-rata selisih waktu hanya 41,76 ms untuk MIUI OS dan 46,52 ms untuk ColorOS.

Kata kunci - mobile application, framework apache cordova, web service, bimbingan tugas akhir.

\section{PENDAHULUAN}

Perkembangan dan pemanfaatan teknologi di berbagai bidang terjadi begitu pesat termasuk pada bidang pendidikan. Salah satu bentuk pemanfaatan teknologi dalam bidang pendidikan adalah pembelajaran daring yang menggunakan internet sebagai media interaksi pembelajaran. Terjadinya pandemi Corona Virus Disease 2019 (Covid-19) memberikan tantangan tersendiri bagi lembaga pendidikan khususnya perguruan tinggi untuk menyelenggarakan pembelajaran secara daring seperti yang disampaikan Kementerian Pendidikan dan Kebudayaan tentang Panduan Penyelenggaraan Pembelajaran di Masa Covid-19 [1].

Implementasi pembelajaran daring selain dilakukan pada perkuliahan juga dapat diterapkan pada proses pembimbingan mahasiswa dalam menyusun tugas akhir. Dalam proses bimbingan, pembimbing dan mahasiswa sebaiknya secara periodik melakukan pertemuan untuk membahas perkembangan dan kendala selama proses bimbingan yang mana hasil pertemuannya dicatat oleh mahasiswa. Kontribusi dan peran dosen pembimbing cukup besar dalam tahapan penyusunan tugas akhir yang meliputi penentuan topik dan tema penelitian serta penyusunan instrumen dan laporan [2]. Namun dalam masa Covid-19, pertemuan tatap muka antara mahasiswa dan dosen dibatasi sehingga dibutuhkan alternatif lain untuk mengatasi hal tersebut.

Pada tahun 2020 terdapat 175,4 juta pengguna internet di Indonesia yang mana $94 \%$ menggunakan perangkat smartphone [3]. Untuk penggunaan sistem operasi dari smartphone sendiri didominasi oleh Android sebesar 91,5\% dan 8,27\% untuk IOS pada oktober 2020[4]. Berdasarkan jumlah tersebut, smartphone dapat dijadikan sebagai media dalam proses pembelajaran daring ini. Pengembangan perangkat lunak untuk pembelajaran daring khususnya proses bimbingan tugas akhir dapat dilakukan pada smartphone. Pada penelitian ini, penulis akan mengembangkan perangkat lunak berbasis android dengan menggunakan Apache Cordova dan web server Apache. Apache Cordova merupakan mobile development framework dengan sumber terbuka yang dapat digunakan secara gratis melalui teknologi web standar seperti HTML5, CSS3 dan Javascript. Penelitian terkait Apache Cordova telah dilakukan oleh Nurwanto dengan judul Implementasi Framework Cordova Sebagai Solusi Pengembangan Aplikasi Cross-Platform. Hasil penelitian menunjukkan aplikasi yang dibangun dengan kode tunggal dapat berjalan 
dengan baik pada platform Android dan browser desktop [5]. Merujuk pada hasil penelitian tersebut maka dalam penelitian yang akan dilaksanakan ini, penulis akan melakukan pengembangan penelitian dengan membangun dan menguji komunikasi data antara aplikasi mobile android yang dibangun melalui Framework Cordova dengan web server Apache menggunakan Hypertext Transfer Protocol (HTTP). Studi kasus dari penelitian ini fokus pada pengembangan Aplikasi Bimbingan Tugas Akhir di STMIK Handayani Makassar sehingga dibutuhkan analisis dan perancangan terlebih dahulu untuk memenuhi kebutuhan Aplikasi.

\section{TINJAUAN PUSTAKA}

\section{A. Pengguna Internet dan Smartphone}

Pengguna internet di Indonesia pada tahun 2020 telah mencapai 175,4 juta. Jumlah ini menunjukkan sekitar $64 \%$ penduduk Indonesia telah merasakan akses Internet. Sebagian besar pengguna internet tersebut menggunakan perangkat smartphone yang mencapai 94\% [3]. Untuk sistem operasi dari smartphone didominasi oleh android dengan persentase $91.5 \%$ pada oktober 2020 [4]. Berdasarkan data tersebut, penelitian ini fokus pada pengembangan dan pengujian perangkat lunak mobile pada sistem operasi android menggunakan Framework Apache Cordova.

\section{B. Framework Apache Cordova}

Apache Cordova merupakan kerangka kerja pengembangan aplikasi mobile menggunakan teknologi web standar HTML5, CSS dan Javascript untuk lintas Platform. Aplikasi akan dibungkus dan dijalankan sesuai platform. Begitupula dengan ketersediaan API yang menyesuaikan dengan perangkat seperti sensor, status jaringan dan lainnya [6]. Penelitian terkait implementasi Apache Cordova telah dilakukan oleh nurwanto [5]. Hasil penelitiannya menunjukkan bahwa aplikasi dapat berjalan dengan baik pada perangkat mobile dengan sistem operasi android dan juga pada browser desktop. Pada penelitian yang akan dilaksanakan ini, penulis akan melakukan pengembangan penelitian dengan membangun dan menguji akses serta komunikasi data antara aplikasi mobile android yang dibangun melalui Framework Cordova dengan web server Apache menggunakan Hypertext Transfer Protocol (HTTP).

\section{Pembelajaran Daring}

Pembelajaran daring merupakan pembelajaran yang memanfaatkan internet untuk aksesibilitas dan kemampuan dalam menyediakan berbagai jenis interaksi pembelajaran. Dalam masa Covid-19, Kementerian Pendidikan dan Kebudayaan telah mengeluarkan kebijakan untuk melakukan pembelajaran daring termasuk perguruan tinggi [1]. Penelitian terkait efektifitas pembelajaran daring telah dilakukan oleh Eko Kuntarto dalam perkuliahan bahasa indonesia di perguruan tinggi [7]. Hasil dari penelitan tersebut menyimpulkan bahwa pembelajaran daring memberikan pengalaman baru yang lebih menantang dan memberikan kebebasan kepada mahasiswa untuk memilih saat yang tepat dalam pembelajaran sehingga penyerapan bahan pembelajaran menjadi lebih tinggi dibandingkan belajar dalam kelas. Berdasarkan uraian tersebut, penelitian terkait pengembangan dan pengujian perangkat lunak mobile akan difokuskan untuk kebutuhan pembelajaran daring.

\section{Efektivitas Bimbingan Tugas Akhir}

Tugas akhir merupakan karya tulis mahasiswa yang menunjukkan proses berpikir ilmiah, kreatif, integratif dan sesuai dengan disiplin ilmu untuk memenuhi persyaratan penyelesaian studi dalam jenjang pendidikan di perguruan tinggi. Dalam prosesnya, penyusunan tugas akhir mahasiswa didampingi oleh dosen pembimbing. Waktu penyelesaian tugas akhir ini sangat dipengaruhi oleh efektifitas bimbingan. Dalam penelitian yang dilakukan oleh yusman et.al. dengan judul efektifitas bimbingan tugas akhir mahasiswa jurusan pendidikan fisika FMIPA UNY, kontribusi dan peran dosen pembimbing cukup besar dalam tahapan penyusunan tugas akhir yang meliputi penentuan topik dan tema penelitian serta penyusunan instrumen dan laporan [8]. Penelitian terkait proktastinasi (penundaan) tugas akhir pernah dilakukan oleh Tatan et.al. Hasil penelitiannya menunjukkan bahwa terdapat 6 faktor yang menyebabkan mahasiswa menunda penyelesaian tugas akhir dan salah satunya adalah layanan bimbingan yang kurang efektif [2]. Merujuk pada hasil penelitian tersebut, penelitian yang akan dilaksanakan ini akan menggunakan studi kasus pengembangan aplikasi mobile android untuk kebutuhan bimbingan tugas akhir.

\section{Metode PENELITIAN}

Pengembangan dan pengujian akses data antara aplikasi mobile berbasis android menggunakan Framework Apache Cordova dan Web Server Apache melalui Hypertext Transfer Protocol (HTTP) dilakukan dalam penelitian. Aplikasi ini digunakan sebagai media penunjang proses bimbingan tugas akhir mahasiswa. Penelitian ini menggunakan metode Research and Development ( $\mathrm{R}$ \& D) dengan menghasilkan sebuah perangkat lunak dan melakukan pengujian. Tahapan penelitian ini dimulai dengan analisis kebutuhan dan pengumpulan data, merancang aplikasi, pembuatan aplikasi berdasarkan rancangan dan pengujian aplikasi. Berikut diagram alur penelitian 


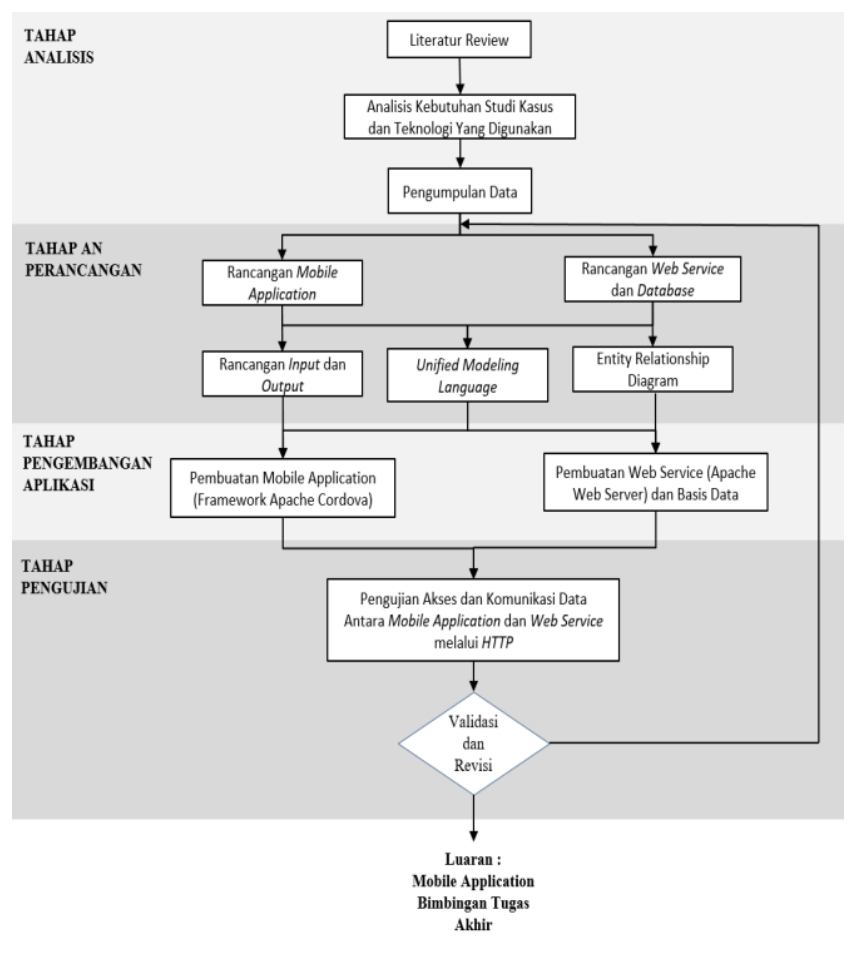

Gambar 1. Diagram Tahap Penelitian

\section{A. Tahap Analisis, Review Literatur dan Pengumpulan Data}

Tahap awal dari penelitian ini yaitu review literatur untuk mendapatkan informasi dan memahami perkembangan teknologi yang dapat diterapkan khususnya Framework Apache Cordova untuk membangun aplikasi hybrid android dan Web Server Apache. Berikut gambaran arsitektur aplikasi berdasarkan hasil analisis dan review literatur.

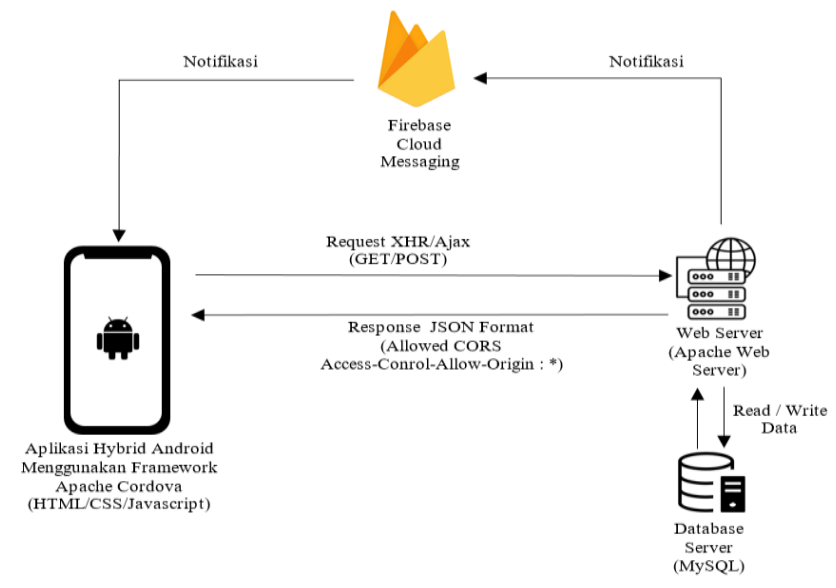

Gambar 2. Arsitektur Aplikasi Dalam Mengakses Web Service

Bahasa pemrograman yang digunakan pada framework Apache Cordova adalah javascript. Pada javascript, terdapat object XMLHttpRequest (XHR) yang dapat digunakan untuk melakukan request data pada server baik menggunakan metode GET maupun POST dengan teknik AJAX
(Asynchronous JavaScript and XML). Penerapan AJAX dalam merekayasa aplikasi web mobile dapat meningkatkan efisiensi bandwidth dan kecepatan muat data secara cukup signifikan [9]. Request ini membutuhkan protokol CORS (Cros-Origin Resource Sharing) karena data yang di-request berada pada domain yang berbeda (web server). Untuk mengizinkan CORS, maka pada web server diberikan attribut Access-Control-Allow-Origin : * [10].

Penelusuran literatur terkait pembelajaran daring juga dilakukan untuk mengetahui tingkat efektifitasnya. Literatur yang digunakan terdiri atas buku, jurnal terbaru dan informasi lainnya yang tersedia di internet. Tahap berikutnya melakukan analisis kebutuhan dan pengumpulan data untuk mengetahui model dan spesifikasi perangkat lunak yang dibutuhkan oleh dosen dan mahasiswa STMIK Handayani dalam proses bimbingan.

\section{B. Perancangan Aplikasi}

Setelah mengetahui informasi, model dan spesikasi yang dibutuhkan oleh pengguna. Berikutnya adalah membuat rancangan basis data dan aplikasinya. Terdapat dua bagian dari aplikasi ini yaitu mobile application dan web service yang menyediakan data. Basis Data terdapat pada web service (web server) yang dirancang menggunakan Entity Relationship Diagram (ERD). Berikut ERD dari aplikasi yang dibangun.

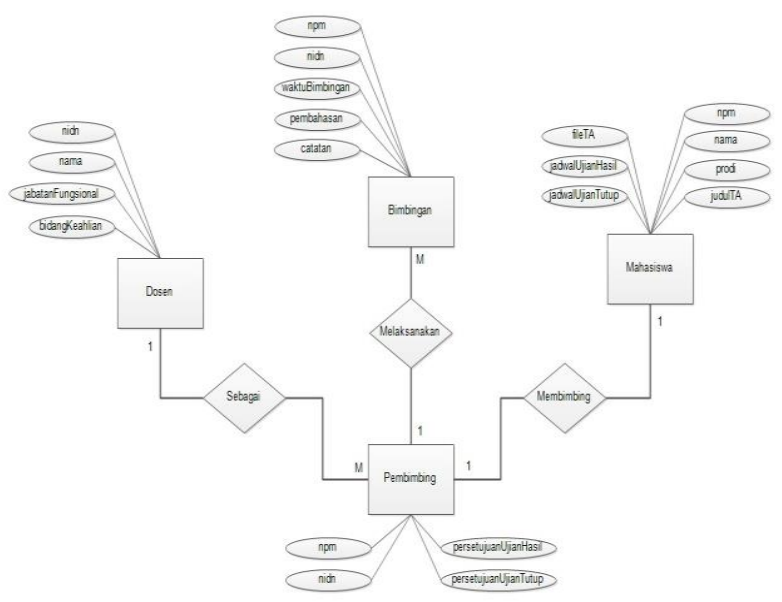

Gambar 4. Entity Relationship Diagram

Diagram diatas menggambarkan bagaimana objek Dosen, Mahasiswa, Pembimbing dan Bimbingan saling berelasi dan atrribut-attributnya. Untuk aplikasi, perancangan dilakukan menggunakan Unified Modelling Langague (UML) yang terdiri atas use case diagram dan class diagram. UML ini digunakan untuk memvisualisasikan alur dan spesifikasi dari aplikasi yang akan dibangun. Berikut usecase diagram dari aplikasi. 


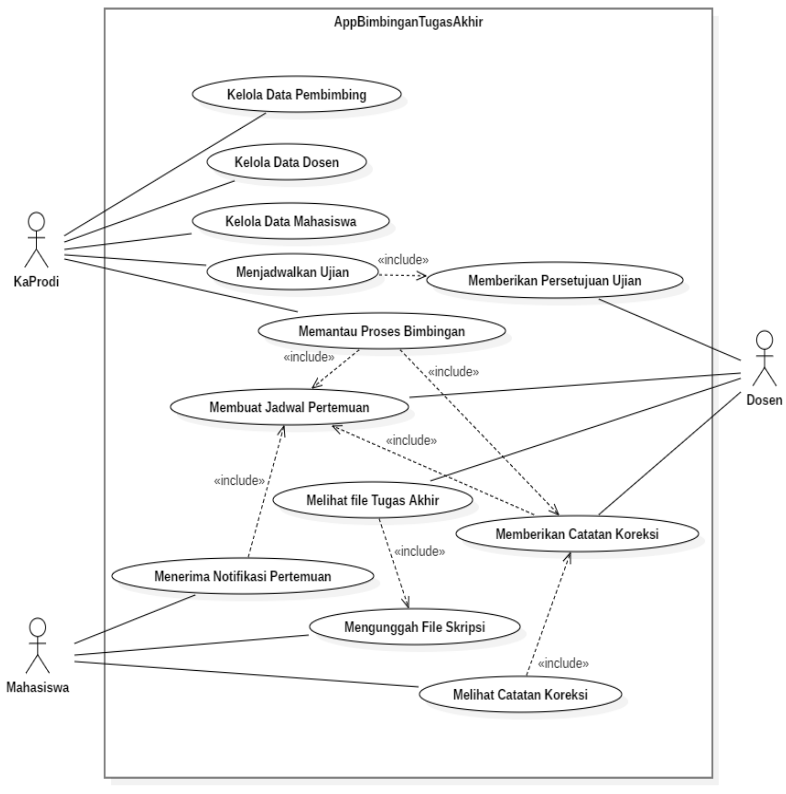

Gambar 5. Usecase Diagram

Terdapat tiga aktor dalam aplikasi yaitu Ketua Program Studi, Dosen dan Mahasiswa. Ketua Program Studi dapat mengelola data Mahasiswa dan Dosen serta memantau proses bimbingan dan melihat daftar mahasiswa yang telah mendapat persetujuan ujian. Mahasiswa menerima pemberitahuan jadwal bimbingan dan dapat mengunggah berkas Tugas Akhir untuk dikoreksi. Sedangkan untuk dosen, terdapat fitur untuk membuat jadwal pertemuan, melakukan koreksi terhadap berkas tugas akhir serta memberikan persetujuan ujian. Untuk class diagram, dapat dilihat pada gambar berikut :

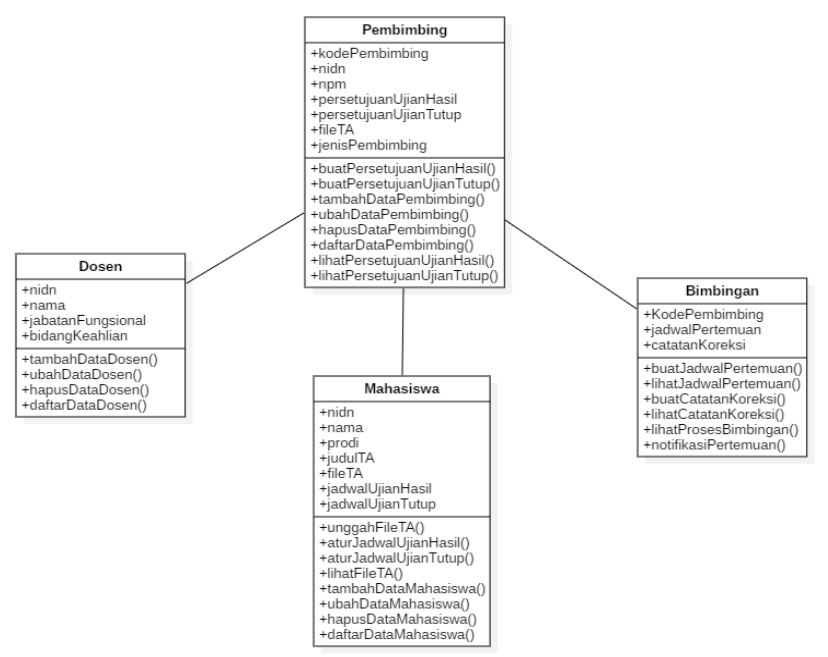

Gambar 6. Class Diagram

Class diagram ini dibangun berdasarkan entity yang terdapat pada entity relationship diagram. Terdapat empat class yang dibentuk yaitu class Dosen, Class Mahasiswa, Class Pembimbing dan Class Bimbingan.

\section{Pembuatan Aplikasi}

Aplikasi yang dibangun mengacu pada rancangan yang telah dibuat sebelumnya. Aplikasi terdiri atas dua bagian. Bagian pertama adalah mobile application berbasis hybrid android yang akan digunakan oleh dosen dan mahasiswa dalam proses bimbingan. Sedangkan aplikasi kedua berupa web service yang menyediakan dan menyimpan data. Mobile application dibangun menggunakan framework cordova dengan basis bahasa HTML, CSS dan Javascript yang akan bertukar informasi dengan server melalui Hypertext Transfer Protocol (HTTP). Berikut antarmuka dari aplikasi hybrid android.

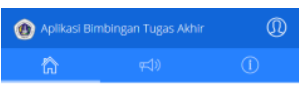

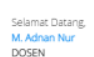

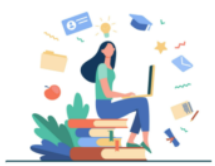

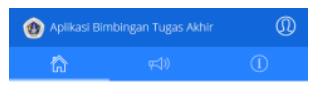

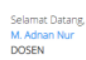

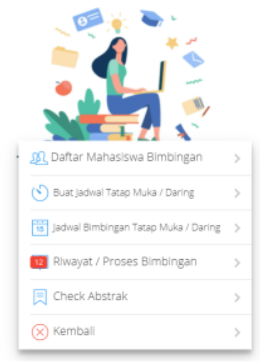

Gambar 7. Antarmuka Aplikasi Android Untuk Dosen
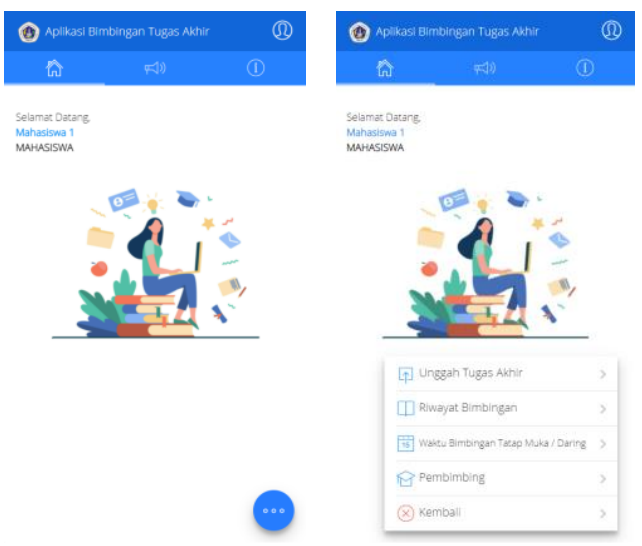

Gambar 8. Antarmuka Aplikasi Android Untuk Mahasiswa

Untuk aplikasi berbasis web dibangun menggunakan bahasa pemrograman server side PHP. Database management system yang digunakan untuk menyimpan basis data adalah MySQL. Web Server dan Database Server tersebut ditempatkan pada server yang sama. Berikut antarmuka dari aplikasi berbasis web yang diperuntukkan untuk Ketua Program Studi. 


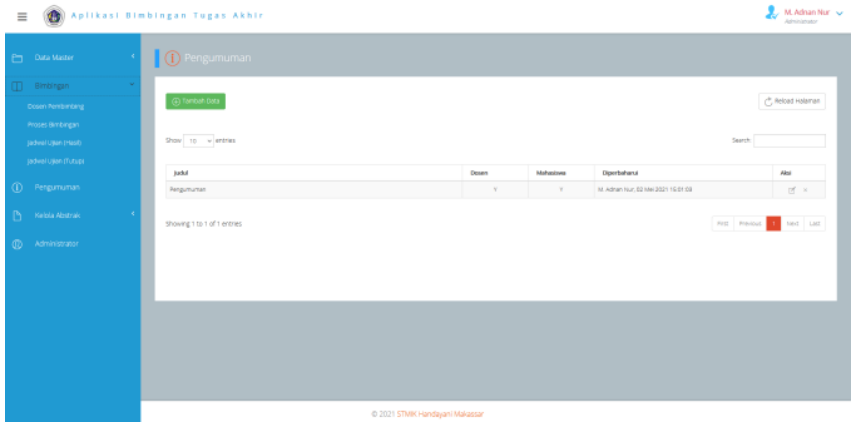

Gambar 9. Antarmuka Aplikasi Web Untuk Ketua Program Studi

\section{Pengujian Aplikasi}

Mobile Application akan diuji pada emulator dan smartphone untuk memastikan apakah sudah sesuai dengan tujuan yang diharapkan. Metode pengujian yang akan digunakan adalah blackbox dengan mengevaluasi antarmuka, fungsionalitas serta akses dan komunikasi data antara mobile application dan web service. Jika terdapat fungsi, antarmuka ataupun data dari aplikasi yang tidak sesuai, peneliti akan meninjau kembali rancangan dan melakukan revisi. Proses tersebut akan berlangsung hingga aplikasi telah memenuhi tujuan yang diharapkan.

\section{HASIL DAN PEMBAHASAN}

Pengujian yang dilakukan pada penelitian ini terletak pada fungsi ataupun antarmuka yang terdapat pada aplikasi hybrid android yang dibangun menggunakan framework apache cordova. Data dan informasi yang disajikan dari setiap fungsi tersebut diperoleh dari web service yang diakses melalui protokol HTTP sehingga penelitian ini juga akan menguji dan membandingkan waktu yang dibutuhkan aplikasi dalam mengakses data dan informasi dari server melalui emulator google chrome dan perangkat android secara langsung. Terdapat dua sistem operasi yang digunakan yaitu MIUI OS versi 10 dari perangkat Android Xiaomi dan Color OS versi dari perangkat Android Oppo. Kedua sistem operasi ini menggunakan versi android yang sama yaitu versi 8.1.

Berdasarkan hasil pengujian blackbox yang dilakukan, seluruh fungsi dapat berjalan sesuai dengan rancangan baik pada emulator maupun perangkat android secara langsung. Sedangkan untuk waktu yang dibutuhkan aplikasi dalam menampilkan data maupun informasi dari web service melalui protocol HTTP dapat dilihat pada tabel berikut.
Tabel 1

Pengujian Fungsi Pada Emulator (Google Chrome)

\begin{tabular}{|c|l|r|}
\hline No & \multicolumn{1}{|c|}{ Fungsi Aplikasi } & $\begin{array}{c}\text { Waktu Akses } \\
\text { Web Services }\end{array}$ \\
\hline 1 & Fungsi Login dan Load Pengguna & $135,5 \mathrm{~ms}$ \\
\hline 2 & Menampilkan Halaman Utama & $99,29 \mathrm{~ms}$ \\
\hline 3 & Menampilkan Halaman Pengumuman & $121,10 \mathrm{~ms}$ \\
\hline 4 & Menyimpan Data Akun & $116,89 \mathrm{~ms}$ \\
\hline 5 & Menampilkan Data Mahasiswa Bimbingan & 109,80 \\
\hline 6 & $\begin{array}{l}\text { Menampilkan Jadwal Bimbingan Tatap } \\
\text { Muka / Daring }\end{array}$ & $112,69 \mathrm{~ms}$ \\
\hline 7 & $\begin{array}{l}\text { Menampilkan Riwayat / Proses } \\
\text { Bimbingan (21 data riwayat) }\end{array}$ & $125,6 \mathrm{~ms}$ \\
\hline 8 & $\begin{array}{l}\text { Mengunggah File Tugas Akhir (Ukuran } \\
\text { 2MB) }\end{array}$ & $10995,29 \mathrm{~ms}$ \\
\hline 9 & Menampilkan Daftar Dosen Pembimbing & $119,2 \mathrm{~ms}$ \\
\hline 10 & Menyimpan Hasil Koreksi Tugas Akhir & $101,7 \mathrm{~ms}$ \\
\hline
\end{tabular}

Tabel 2

Pengujian Fungsi Pada Perangkat Android Bersistem OPERasi MIUI OS VERSI 10 (MI 8 SE)

\begin{tabular}{|c|l|r|}
\hline No & \multicolumn{1}{|c|}{ Fungsi Aplikasi } & \multicolumn{1}{|c|}{$\begin{array}{l}\text { Waktu Akses } \\
\text { Web Services }\end{array}$} \\
\hline 1 & Fungsi Login dan Load Pengguna & $230,59 \mathrm{~ms}$ \\
\hline 2 & Menampilkan Halaman Utama & $161,7 \mathrm{~ms}$ \\
\hline 3 & Menampilkan Halaman Pengumuman & $160,79 \mathrm{~ms}$ \\
\hline 4 & Menyimpan Data Akun & $148 \mathrm{~ms}$ \\
\hline 5 & Menampilkan Data Mahasiswa Bimbingan & $181,3 \mathrm{~ms}$ \\
\hline 6 & $\begin{array}{l}\text { Menampilkan Jadwal Bimbingan Tatap } \\
\text { Muka / Daring }\end{array}$ & $\begin{array}{l}\text { Menampilkan Riwayat / Proses } \\
\text { Bimbingan (21 data riwayat) }\end{array}$ \\
\hline 7 & $\begin{array}{l}\text { Mengunggah File Tugas Akhir (Ukuran } \\
\text { 2MB) }\end{array}$ & $10029,2 \mathrm{~ms}$ \\
\hline 9 & Menampilkan Daftar Dosen Pembimbing & $128,19 \mathrm{~ms}$ \\
\hline 10 & Menyimpan Hasil Koreksi Tugas Akhir & $101,7 \mathrm{~ms}$ \\
\hline
\end{tabular}

Tabel 3

Pengujian Fungsi Pada PerangKat ANDRoId Bersistem OPERASI COLOROS VERSI 5.2.1 (OPPO A3s)

\begin{tabular}{|c|l|l|}
\hline \multirow{2}{*}{ No } & \multicolumn{1}{|c|}{ Fungsi Aplikasi } & \multicolumn{1}{|c|}{$\begin{array}{l}\text { Waktu Akses } \\
\text { Web Services }\end{array}$} \\
\hline 1 & Fungsi Login dan Load Pengguna & $208,39 \mathrm{~ms}$ \\
\hline 2 & Menampilkan Halaman Utama & $156,90 \mathrm{~ms}$ \\
\hline 3 & Menampilkan Halaman Pengumuman & $141,09 \mathrm{~ms}$ \\
\hline 4 & Menyimpan Data Akun & $151 \mathrm{~ms}$ \\
\hline 5 & Menampilkan Data Mahasiswa Bimbingan & $175,59 \mathrm{~ms}$ \\
\hline 6 & $\begin{array}{l}\text { Menampilkan Jadwal Bimbingan Tatap } \\
\text { Muka / Daring }\end{array}$ & $161,79 \mathrm{~ms}$ \\
\hline 7 & $\begin{array}{l}\text { Menampilkan Riwayat / Proses } \\
\text { Bimbingan (21 data riwayat) }\end{array}$ & $254,8 \mathrm{~ms}$ \\
\hline 8 & $\begin{array}{l}\text { Mengunggah File Tugas Akhir (Ukuran } \\
\text { 2MB) }\end{array}$ & $13051 \mathrm{~ms}$ \\
\hline 9 & Menampilkan Daftar Dosen Pembimbing & $134,09 \mathrm{~ms}$ \\
\hline 10 & Menyimpan Hasil Koreksi Tugas Akhir & 175,79 \\
\hline
\end{tabular}

Waktu akses yang disajikan pada tabel diatas merupakan waktu tercepat dari beberapa kali pengujian untuk setiap fungsi dengan menggunakan koneksi internet yang sama dan diwaktu yang bersamaan. Perbandingan waktu akses aplikasi dari emulator dan perangkat android dapat dilihat pada grafik berikut. 


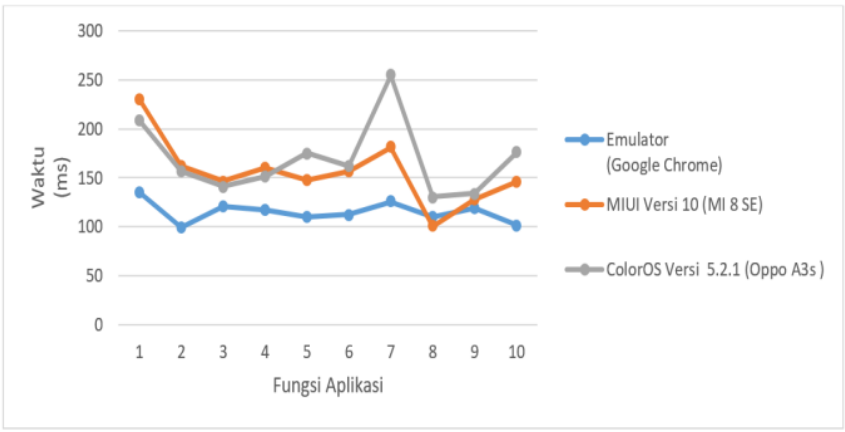

Gambar 10. Perbandingan Waktu Akses Web Service Pada Emulator dan Perangkat Android

Waktu akses dari fungsi 8 pada grafik diatas merupakan nilai perseratus agar perbedaan waktu tidak begitu signifikan dengan fungsi lainnya. Pada grafik diatas terlihat bahwa sebagian besar waktu akses web service dengan emulator lebih cepat dibandingkan menggunakan perangkat android secara langsung baik dengan MIUI OS maupun ColorOS. Emulator hanya lebih lambat pada saat mengunggah file tugas akhir, sedangkan untuk mengakses data ataupun informasi lainnya melalui emulator lebih cepat dengan rata-rata perbedaan 41,76 ms untuk MIUI OS dan 46,5 ms untuk ColorOS. Untuk perbandingan MIUI OS dan ColorOS, pada fungsi 1- 4 ColorOS lebih cepat dari MIUI OS dengan rata-rata perbedaan waktu rata-rata $10,42 \mathrm{~ms}$ sedangkan untuk fungsi 5 - 10, MIUI OS lebih dengan dengan perbedaan waktu rata-rata $28,67 \mathrm{~ms}$.

\section{KESIMPULAN}

Berdasarkan hasil pengujian yang telah dilakukan, mobile application hybrid yang dibangun dengan framework apache cordova dapat mengakses data dan informasi pada web service melalui protokol HTTP dengan Object XHR Javascript baik pada emulator maupun perangkat android. Terdapat perbedaan waktu ketika data diakses pada emulator dan perangkat android namun selisih waktu tidak begitu signifikan. Emulator dengan google chrome lebih cepat dalam request data server dibandingkan perangkat android dengan MIUI OS dan ColorOS. Terdapat 4 fungsi yang menunjukkan ColorOS lebih cepat dalam mengakses data dari MIUI OS sedangkan 6 fungsi lainnya menunjukkan MIUI OS lebih cepat.

\section{DAFTAR ACUAN}

[1] K. P. dan Kebudayaan, "Panduan Penyelenggaraan Pembelajaran pada Tahun Ajaran dan Tahun Akademik Baru di Masa Covid-19," 2020.

https://www.kemdikbud.go.id/main/blog/2020/06/pandua n-penyelenggaraan-pembelajaran-pada-tahun-ajaran-dantahun-akademik-baru-di-masa-covid19 (accessed Sep. 10, 2020).

[2] T. Z. Mutakien, "Analisis Prokrastinasi Tugas Akhir/Skripsi," Form. J. Ilm. Pendidik. MIPA, vol. 2, no. 1, pp. 82-89, 2015, doi: 10.30998/formatif.v2i1.87.

[3] Detikcom, "Riset: Ada 175,2 Juta Pengguna Internet di Indonesia," 2020. https://inet.detik.com/cyberlife/d4907674/riset-ada-1752-juta-pengguna-internet-diindonesia (accessed Sep. 10, 2020).

[4] StatCounter, "Mobile Operating System Market Share Indonesia," 2020. https://gs.statcounter.com/os-marketshare/mobile/indonesia (accessed Sep. 10, 2020).

[5] N. Nurwanto, "Implementasi Framework Cordova Sebagai Solusi Pengembangan Aplikasi Cross-Platform," J. SITECH Sist. Inf. dan Teknol., vol. 2, no. 1, pp. 67-70, 2019, doi: 10.24176/sitech.v2i1.3396.

[6] A. Cordova, "Apache Cordova." https://cordova.apache.org/blog.

[7] E. Kuntarto, "Keefektifan Model Pembelajaran Daring Dalam Perkuliahan Bahasa Indonesia di Perguruan tinggi," J. Indones. Lang. Educ. Lit., vol. 3, no. 1, pp. 5365, 2017.

[8] Y. Wiyatmo, "Efektivitas Bimbingan Tugas Akhir Skripsi ( Tas ) Mahasiswa Jurusan Pendidikan Fisika Fmipa Uny," Pros. Semin. Nas. Penelitian, Pendidik. dan Penerapan MIPA, Fak. MIPA, Univ. Negeri Yogyakarta, pp. 405-414, 2010.

[9] T. Wijaya, "Penerapan AJAX dalam Aplikasi Mobile Berbasis Web Untuk Meningkatkan Efisiensi Bandwidth," Techno.Com, vol. 17, no. 2, pp. 197-207, 2018, doi: 10.33633/tc.v17i2.1687.

[10] W3C, “CORS Enabled," https://www.w3.org, 2015. https://www.w3.org/wiki/CORS_Enabled. 